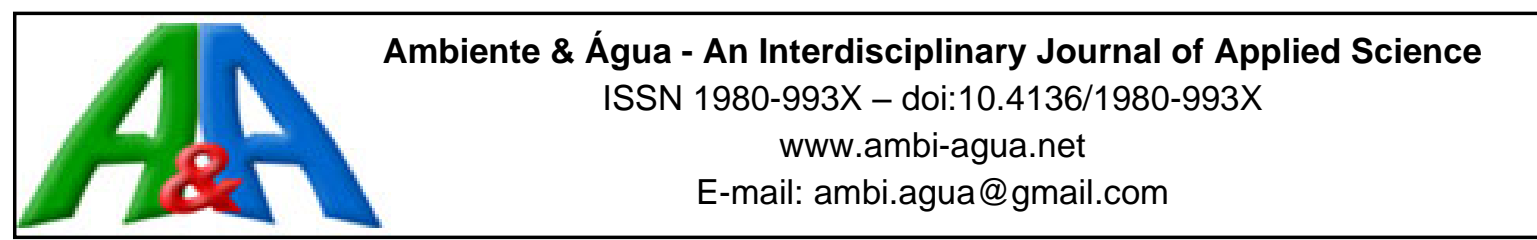

\title{
Effect of hydraulic retention time on chemical oxygen demand and total nitrogen removal in intermittently aerated constructed wetlands
}

\author{
ARTICLES doi:10.4136/ambi-agua.2504
}

Received: 05 Dec. 2019; Accepted: 30 Mar. 2020

\begin{abstract}
Isabela Pires da Silva ${ }^{1,2}$; Gabriela Barbosa da Costa ${ }^{1,2}(\mathbb{D}$; João Gabriel Thomaz Queluz ${ }^{1,2 *(D)}$; Marcelo Loureiro Garcia1(iD

${ }^{1}$ Instituto de Geociências e Ciências Exatas. Universidade Estadual Paulista "Júlio de Mesquita Filho" (UNESP), Avenida 24-A, n 1515, CEP: 13506-900, Rio Claro, SP, Brazil. E-mail: isa_bela_pires@ @otmail.com, gabrielacosta-1997@hotmail.com,marcelo.garcia@unesp.br

${ }^{2}$ Centro de Estudos Ambientais. Universidade Estadual Paulista "Júlio de Mesquita Filho" (UNESP), Avenida 24-A, n 1515, CEP: 13506-900, Rio Claro, SP, Brazil. E-mail: isa_bela_pires@ @otmail.com, gabrielacosta-1997@hotmail.com

*Corresponding author. E-mail: j.queluz@unesp.br
\end{abstract}

\begin{abstract}
This study evaluated the effect of hydraulic retention time on chemical oxygen demand (COD) and total nitrogen (TN) removal in an intermittently aerated constructed wetlands. Two horizontal subsurface-flow constructed wetlands were used: one without aeration and the other aerated intermittently ( 1 hour with aeration/7 hours without aeration). Both systems were evaluated treating domestic wastewater produced synthetically. The flow rate into the two CWs was $8.6 \mathrm{~L} \mathrm{day}^{-1}$ having a hydraulic retention time of 3 days. The results show that the intermittently aerated constructed wetland were highly efficient in removing COD $(98.25 \%)$, TN $(83.60 \%)$ and total phosphorus $(78.10 \%)$, while the non-aerated constructed wetland showed lower efficiencies in the removal of COD (93.89\%), TN (48.60\%) and total phosphorus (58.66). These results indicate, therefore, that intermittent aeration allows the simultaneous occurrence of nitrification and denitrification processes, improving the removal of $\mathrm{TN}$ in horizontal subsurface-flow constructed wetlands. In addition, the use of intermittent aeration also improves the performance of constructed wetlands in removing COD and total phosphorus.
\end{abstract}

Keywords: ecotechnology, effluent treatment, nutrients removal.

\section{Remoção de DQO e Nitrogênio Total em alagados construídos com aeração intermitente em relação ao tempo de detenção hidráulica}

\section{RESUMO}

O objetivo do presente trabalho foi avaliar o efeito do tempo de detenção hidráulica na remoção da demanda química de oxigênio (DQO) e nitrogênio total (NT) em alagados construídos aerados intermitente. Foram utilizados dois alagados construídos de fluxo subsuperficial horizontal: um sem aeração e outro aerado intermitentemente (1 hora com aeração/7 hora sem aeração). Ambos os sistemas foram avaliados tratando água residuária doméstica sintética. Cada sistema recebeu uma vazão de $8,6 \mathrm{~L} \mathrm{dia}^{-1}$, resultando em tempo de detenção de 3 dias. Os resultados mostram que o alagado construído aerado intermitentemente apresentou elevada eficiência na remoção de DQO $(98,25 \%)$, NT $(83,60 \%)$ e fósforo total

This is an Open Access article distributed under the terms of the Creative Commons Attribution License, which permits unrestricted use, distribution, and reproduction in any medium, provided the original work is properly cited. 
$(78,10 \%)$, enquanto que o sistema sem aeração apresentou menor eficiência na remoção de DQO $(93,89 \%)$, NT $(48,60 \%)$ e fósforo total $(58,66 \%)$. Esses resultados indicam, portanto, que a aeração intermitente permite a ocorrência simultânea dos processos de nitrificação e desnitrificação, melhorando a remoção de NT em alagados construídos de fluxo subsuperficial horizontal. Além disso, o uso de aeração intermitente também melhora o desempenho de alagados construídos na remoção de DQO e fósforo total.

Palavras-chave: ecotecnologia, remoção de nutrientes, tratamento de efluente.

\section{INTRODUCTION}

Constructed wetland $(\mathrm{CW})$ is a simple technology which not only mimics the functions of a natural wetland but is easy to operate and maintain and cost-effective (Al-Isawi et al., 2015; 2017). In recent decades, it has garnered increasing interest in the treatment of several types of wastewater rich in biodegradable organic materials (Matos et al., 2010a). Its main component is the support medium, which can be composed of soil, sand, gravel, plant species characteristic of wetland environments, and microorganisms associated with these elements. Its design is generally aimed at maximizing the wastewater treatment efficiencies (Fia, 2009).

Macrophytes play an important treatment role in CWs, especially in systems with large amounts of organic matter and ammonia (Ciria et al., 2005). The most commonly used plants are cattail (Typha sp.), common reed (Phragmites sp.), and bulrush (Scirpus sp.) (Matos and Lo Monaco, 2003). However, plant characteristics such as local climate adaptability, photosynthetic rate, oxygen transport capacity, pollutant absorption capacity, resistance to pests and diseases, and root system development should be considered.

According to Suliman et al. (2004), the main variables considered while designing CWs are the hydraulic retention time (HRT), width, height and length, and hydraulic application rate. The hydraulic load and HRT significantly influence the efficiency in CWs (Wu et al., 2015). Low HRT can be associated with inefficient denitrification, with a longer retention time required for nitrogen removal compared to that required for organic matter removal (Lee et al., 2009).

The present study therefore evaluated the dynamics of chemical oxygen demand (COD) and total nitrogen (TN) removal in relation to the HRT in intermittently aerated horizontal subsurface-flow constructed wetlands.

\section{MATERIALS AND METHODS}

The experiment was conducted in a green-house environment located at the Center for Environmental Studies (Centro de Estudos Ambientais - CEA) of the Institute of Geosciences and Exact Sciences - UNESP, Rio Claro, São Paulo, Brazil. The climate of the region is defined as Cwa (Koppën): warm temperate climate (mesothermal) with rainy summer and dry winter, with the temperature of the hottest month averaging over $22^{\circ} \mathrm{C}$. The average annual precipitation and average annual temperatures are $1366.8 \mathrm{~mm}$ and $21.6^{\circ} \mathrm{C}$, respectively.

Two horizontal subsurface-flow constructed wetlands were evaluated: one without aeration (CW1) and the other aerated intermittently (CW2). Each treatment system was composed of a rectangular polypropylene water tank with a capacity of $\sim 61 \mathrm{~L}$ and dimensions of $310 \times 355 \times 555 \mathrm{~mm}$. The media used was gravel $(2 \leq \varnothing \leq 9 \mathrm{~mm})$ with a porosity of $53 \%$, having an height of $30 \mathrm{~cm}$ and saturated by the effluent up to a height of $25 \mathrm{~cm}$ with a useful volume of $26 \mathrm{~L}$. Two 32-mm PVC perforated tubes were installed in the longitudinal section of each constructed wetland with $18.5-\mathrm{cm}$ spacing between them so that wastewater samples could be collected in the system. 
$\mathrm{CW} 2$ was aerated intermittently for $3 \mathrm{~h} \mathrm{day}^{-1}(1 \mathrm{~h}$ aeration/ $7 \mathrm{~h}$ non aeration $)$ at an average aeration rate of $20 \mathrm{~L} \mathrm{~min}^{-1}$, resulting in an oxygen surface application rate of $\sim 101.5 \mathrm{~L} \mathrm{~m}^{-2} \mathrm{~min}^{-}$ 1. The air was applied to the system using an aquarium air compressor and a tubular air diffuser installed inside the constructed wetland support material.

The aquatic macrophyte species used in the CWs was cattail (Typha latifolia), which was collected from a natural swamp and pruned at half height. The replanting of macrophytes in the CWs was carried out on March 07, 2018, and the planting density was approximately 15 plants per $\mathrm{m}^{2}$, that is, each system was cultivated with three plants. During the period of macrophyte fixation, the constructed wetlands were saturated with water and only on April 4, 2018, after the fixation of the plant species, was the application of wastewater started.

Figure 1 shows the schematic diagram of the CWs.

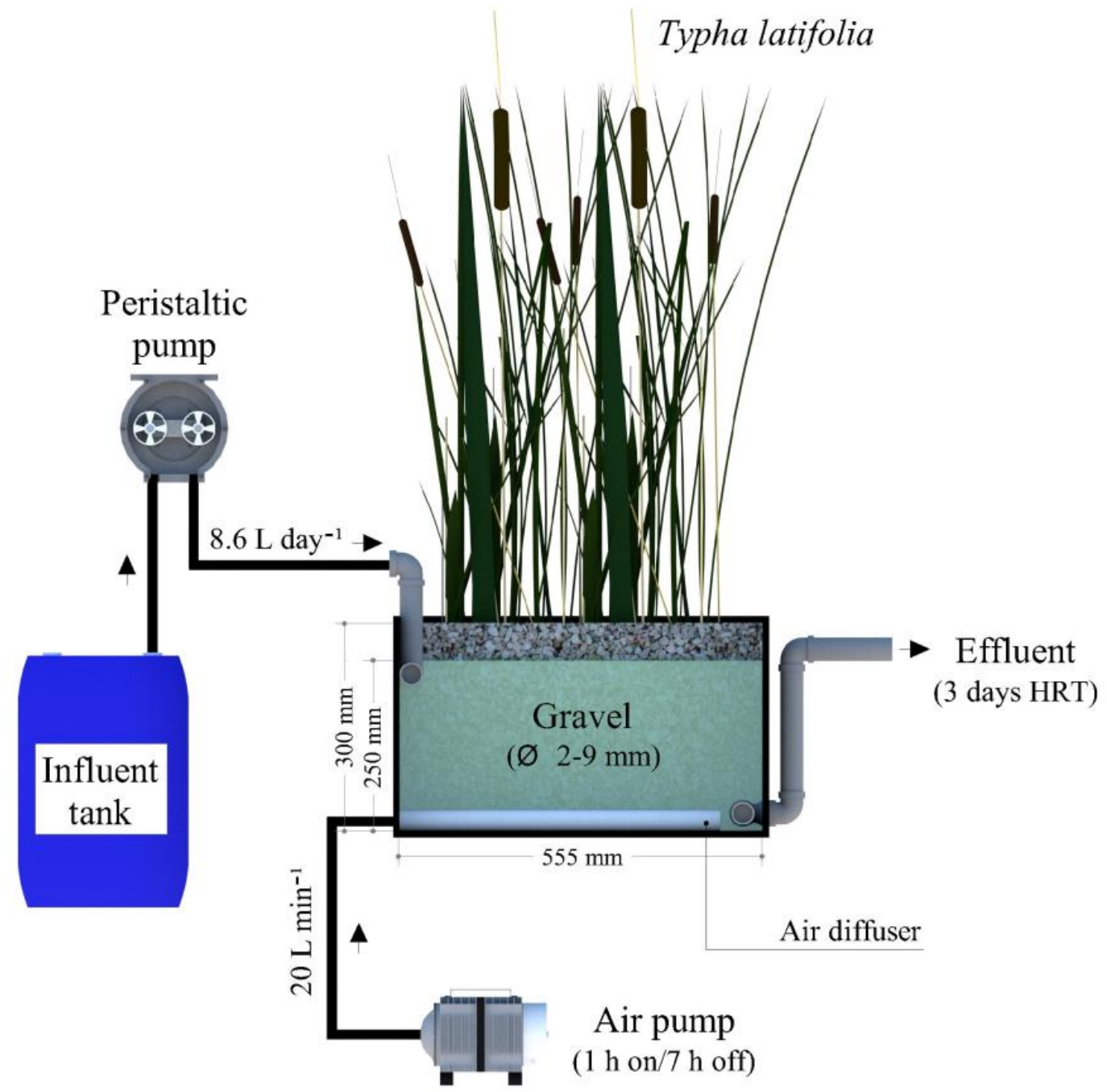

Figure 1. Schematic diagram of the CWs used in the experiment.

The CWs were operated from April 4, 2018 to December 7, 2018, that is, the systems were kept in operation for 250 consecutive days. The experiment was conducted using synthetic wastewater prepared with tap water with the addition of $\mathrm{C}_{12} \mathrm{H}_{22} \mathrm{O}_{11}$ (sucrose), $\left(\mathrm{NH}_{4}\right)_{2} \mathrm{SO}_{4}$ (ammonium sulfate), $\mathrm{KH}_{2} \mathrm{PO}_{4}$ (monopotassium phosphate), $\mathrm{MgSO}_{4}$ (magnesium sulfate), $\mathrm{FeSO}_{4}$ (iron(II) sulfate), and $\mathrm{CaCl}_{2}$ (calcium chloride), equal to the synthetic effluent used in Wu et al. (2015), Fan et al. (2016), and Wu et al. (2016) works. Table 1 shows the compounds and their respective concentrations used in the synthetic effluent. 
Table 1. Composition of the synthetic primary effluent.

\begin{tabular}{cc}
\hline Chemical compound* & Concentration $\left(\mathbf{m g ~ L}^{\mathbf{- 1}}\right)$ \\
\hline $\mathrm{C}_{12} \mathrm{H}_{22} \mathrm{O}_{11}$ & 386 \\
$\left(\mathrm{NH}_{4}\right)_{2} \mathrm{SO}_{4}$ & 188 \\
$\mathrm{KH}_{2} \mathrm{PO}_{4}$ & 18 \\
$\mathrm{MgSO}_{4}$ & 10 \\
$\mathrm{FeSO}_{4}$ & 10 \\
$\mathrm{CaCl}_{2}$ & 10 \\
\hline
\end{tabular}

* Chemical compounds were diluted in tap water to prepare the synthetic effluent.

Source: Wu et al. (2015), Fan et al. (2016) and Wu et al. (2016).

The effluent was applied to the CWs using peristaltic pumps, with a hydraulic loading rate of $0.044 \mathrm{~m}^{3} \mathrm{~m}^{-2} \mathrm{~d}^{-1}\left(8,6 \mathrm{~L} \mathrm{~d}^{-1}\right)$. Therefore, considering the saturated volume of the CWs and the hydraulic loading rate, it was estimated that the HRT was approximately 3 days. However, as perforated tubes were installed along the longitudinal section in each water tank, it was possible to evaluate the concentration of pollutants according to the distance from the entry point of the influent and, consequently, according to different HRT: 0, 1, 2, and 3 days.

In the period from November 1, 2018 to December 7, 2018, five effluent samples were collected from each sampling point, and following parameters were analyzed: COD, TN, ammonium $\left(\mathrm{NH}_{4}{ }^{+}\right)$, nitrite $\left(\mathrm{NO}_{2}{ }^{-}\right)$, nitrate $\left(\mathrm{NO}_{3}{ }^{-}\right)$, total phosphorus (TP), potential of hydrogen $(\mathrm{pH})$, and temperature. The analyses were performed at CEA-UNESP, Rio Claro Campus, according to the methodologies described in Standard Methods (APHA et al., 2012).

\section{RESULTS AND DISCUSSION}

The characteristics of the influent and effluent throughout the CWs and their respective removal efficiencies are shown in Table 2.

Table 2. Physico-chemical characteristics of the influent and effluent along the CWs and their respective removal efficiencies $(\varepsilon)$.

\begin{tabular}{lccccccc}
\hline & & \multicolumn{3}{c}{ HRT (d) CW1 } & \multicolumn{3}{c}{ HRT (d) CW2 } \\
\cline { 3 - 8 } Parameter & Effluent & 1 & 2 & 3 & 1 & 2 & 3 \\
\hline $\mathrm{COD}\left(\mathrm{mg} \mathrm{L}^{-1}\right)$ & $388 . \pm 19.7$ & $119 \pm 29.9$ & $43 \pm 10.4$ & $23.8 \pm 6.6$ & $42.2 \pm 15$ & $9.6 \pm 5.6$ & $6.8 \pm 2.9$ \\
$\varepsilon(\%)$ & - & $69.37 \pm 8.0$ & $88.98 \pm 2.5$ & $93.89 \pm 1.6$ & $89.24 \pm 3.6$ & $97.51 \pm 1.5$ & $98.25 \pm 0.8$ \\
$\mathrm{NH}_{4}^{+}\left(\mathrm{mg} \mathrm{L}^{-1}\right)$ & $39.16 \pm 6.2$ & $25.08 \pm 5.6$ & $18.86 \pm 8$ & $16.48 \pm 2.3$ & $6.52 \pm 3.3$ & $0.82 \pm 1.9$ & $0.58 \pm 0.6$ \\
$\varepsilon(\%)$ & - & $35.64 \pm 7.9$ & $51.54 \pm 9.7$ & $57.72 \pm 4.5$ & $83.23 \pm 3.6$ & $97.89 \pm 2.1$ & $98.52 \pm 0.7$ \\
$\mathrm{NO}_{2}^{-}\left(\mathrm{mg} \mathrm{L}^{-1}\right)$ & 0.0042 & $0.043 \pm 0.04$ & $0.03 \pm 0.05$ & $0.019 \pm 0.01$ & $0.059 \pm 0.04$ & $0.027 \pm 0.02$ & $0.048 \pm 0.08$ \\
$\mathrm{NO}_{3}{ }^{-}\left(\mathrm{mg} \mathrm{L}^{-1}\right)$ & $1.36 \pm 0.3$ & $8.02 \pm 1.2$ & $3.96 \pm 1.3$ & $4.26 \pm 1.6$ & $6.98 \pm 2.6$ & $7.9 \pm 1.4$ & $5.98 \pm 1.1$ \\
$\mathrm{TN}\left(\mathrm{mg} \mathrm{L}^{-1}\right)$ & $40.52 \pm 2.1$ & $33.14 \pm 3.3$ & $22.85 \pm 5.0$ & $20.76 \pm 3.1$ & $13.56 \pm 3.2$ & $8.75 \pm 1.8$ & $6.61 \pm 1.16$ \\
$\varepsilon(\%)$ & - & $17.81 \pm 8.8$ & $43.40 \pm 9.3$ & $48.60 \pm 6.3$ & $66.42 \pm 7.2$ & $78.23 \pm 4.7$ & $83.60 \pm 3.2$ \\
$\mathrm{TP}\left(\mathrm{mg} \mathrm{L}^{-1}\right)$ & $3.88 \pm 0.48$ & - & - & $1.58 \pm 0.56$ & - & - & $0.89 \pm 0.69$ \\
$\varepsilon(\%)$ & - & - & - & $58.66 \pm 17.8$ & - & - & $78.1 \pm 16.36$ \\
$\mathrm{pH}$ & $6.96 \pm 0.25$ & - & - & $7.09 \pm 0.45$ & - & - & $6.68 \pm 0.49$ \\
$\mathrm{~S}\left(\mu \mathrm{S} \mathrm{cm}{ }^{-1}\right)$ & $562 \pm 19.3$ & - & - & $397 \pm 15.6$ & - & - & $578.5 \pm 72.8$ \\
$\mathrm{~T}\left({ }^{\circ} \mathrm{C}\right)$ & $23.0 \pm 1.5$ & - & - & $21.5 \pm 1.7$ & - & - & $20.3 \pm 1.8$ \\
\hline
\end{tabular}

All samples were collected and analyzed between November 1, 2018 to December 7, 2018 (Mean $\pm \mathrm{SD}, \mathrm{n}=5$ ). 


\subsection{Chemical Oxygen Demand}

Figure 2 shows the average COD concentrations along the CWs. The removal efficiencies of both systems within 3 days of HRT was high, with similar removal efficiencies of $93.89 \%$ for CW1 and $98.25 \%$ for CW2. Similar values were reported in the literature, for example, Matos et al. (2010b) obtained, with HRT of $\sim 4.8$ days, COD removal efficiencies ranging from $71 \%$ to $96 \%$ in non-aerated horizontal subsurface-flow constructed wetlands treating hog wastewater; Brasil et al. (2005) obtained, in non-aerated horizontal subsurface-flow constructed wetlands treating domestic wastewater, average COD removal efficiencies of $84 \%$ and $93 \%$ for HRTs of 1.9 and 3.8 days, respectively; and Wu et al. (2016) obtained, in intermittent-aerated vertical subsurface-flow constructed wetlands treating synthetic wastewater, COD removal efficiencies $>95 \%$ for HRT of 3 days.

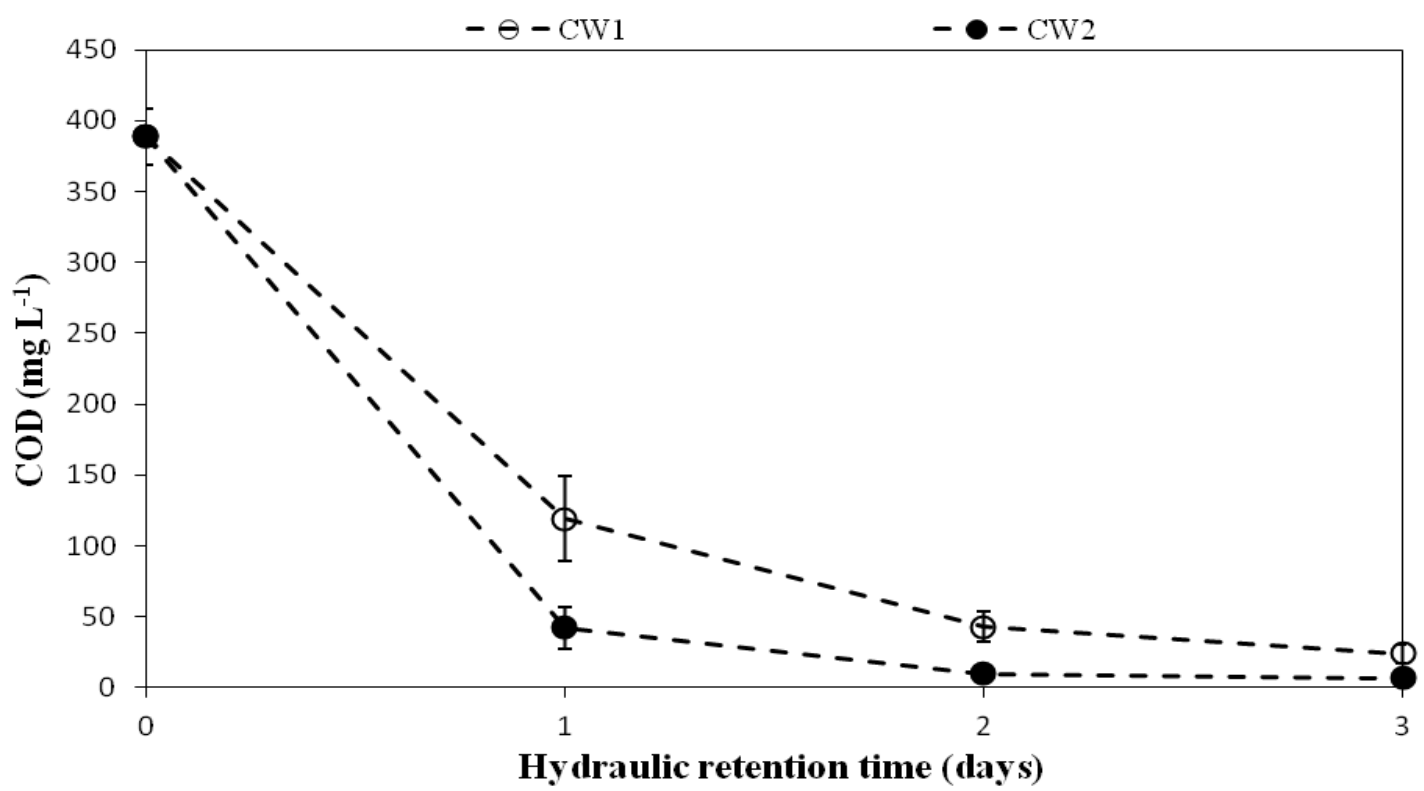

Figure 2. Average COD concentrations along both CWs.

However, the removal efficiency of CW2 for HRT of 1 day was $89.24 \pm 3.57 \%$, while the value obtained for CW1 was $69.37 \pm 8.04 \%$ (Table 2). The results of the present work are similar to the data reported by Wu et al. (2016), in which the authors evaluated vertical subsurface-flow constructed wetlands and with a HRT of 12 hours obtained in intermittent aerated systems and in non-aerated systems COD removal efficiencies of $>88 \%$ and $76-82 \%$, respectively. The higher efficiency of CW2 compared to that of CW1 after 1day HRT can be attributed to the intermittent artificial aeration, which stimulates the increase of biological activity, thereby contributing to a high efficiency of COD removal, nitrification, and denitrification. This is because during aeration periods aerobic heterotrophic microorganisms use organic matter as a source of energy, leading to COD removal. Moreover, during nonaeration periods (anoxic), denitrifying heterotrophic microorganisms remove COD (Wendling, 2017), indicating the occurrence of denitrification.

Our results indicate, therefore, that the use of intermittent aeration improves the COD removal performance of horizontal subsurface-flow constructed wetlands, corroborating the results reported by Wu et al. (2015), in which the authors achieved COD removal efficiencies ranging from 96.42 to $98.49 \%$ in intermittently aerated CWs, and ranging from 62.68 to $85.49 \%$ in non-aerated systems.

\subsection{Nitrogen removal}

The dynamics of nitrogen removal along the CWs can be seen in Figure 3. The results obtained in the present study show that the final average concentration in CW1 was 
$16.48 \mathrm{mg} \mathrm{L}^{-1}$ and $20.76 \mathrm{mg} \mathrm{L}^{-1}$ for $\mathrm{NH}_{4}{ }^{+}$and $\mathrm{TN}$, respectively. Thus, the mean final removal efficiency (Table 2) of CW1 is $57.7 \pm 4.5 \%$ and $48.6 \pm 6.3 \%$ while in CW2, it is $98.5 \pm 0.7 \%$ and $83.6 \pm 3.2 \%$ for $\mathrm{NH}_{4}{ }^{+}$and TN, respectively. Although the removal efficiencies of CW1 for $\mathrm{NH}_{4}{ }^{+}$and TN with only 1 day of HRT are $35.64 \pm 7.9 \%$ and $17.8 \pm 8.8 \%$, respectively, CW2 has a removal efficiency of $83.23 \pm 3.6 \%$ and $66.4 \pm 7.17 \%$ with the same HRT. That is, the efficiency levels of the aerated system increase by $\sim 47.6 \%$ for $\mathrm{NH}_{4}{ }^{+}$and by $48.6 \%$ for $\mathrm{TN}$, thereby surpassing the final removal efficiency rates of CW1 in the first 24 hours of treatment.
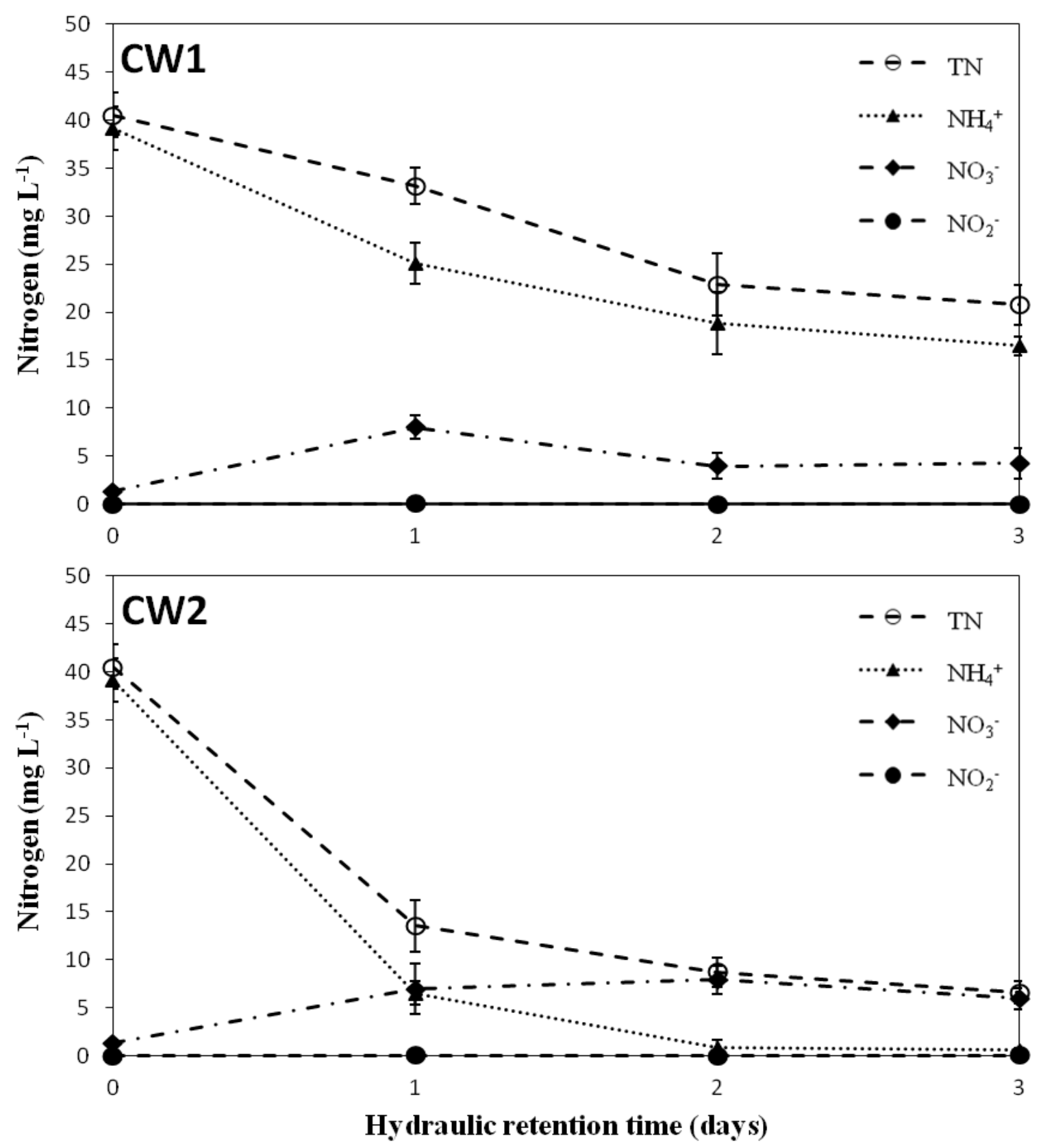

Figure 3. Dynamics of nitrogen removal along the CWs.

The TN and $\mathrm{NH}_{4}{ }^{+}$removal efficiencies in the CW2 can be considered satisfactory, since the average values obtained are higher than those reported in the literature for non-aerated constructed wetlands. Ramos et al. (2017) reported average TN removal efficiencies of 38-48\% in systems planted with Polygonum punctatum and Chrysopogon zizanioides with HRT of 3.2 days. It should be noted that these removal efficiencies were exceeded in only 24 hours in our 
CW2 system. The results obtained by Wang et al. (2016) showed a mean removal efficiency of $46 \%$ for $\mathrm{NH}_{4}{ }^{+}$and $43 \%$ for TN in CWs planted with Canna indica L. with 5-day HRT. The removal efficiencies obtained in CW2 for both parameters in 1 day of HRT were significantly higher than the values obtained by those authors. Therefore, our results indicate that intermittent aeration has enhanced the aerobic environment for nitrifiers and, in addition, the cattails have aerenchyma tissues that transport oxygen from above-ground parts into the below-ground parts, that is, the macrophyte roots released oxygen in the soil media, also increasing aerobic microbial activity. Both these mechanisms improved the $\mathrm{NH}_{4}^{+}$and $\mathrm{TN}$ removal through nitrification and also plant uptake.

Due to the predominantly anaerobic conditions non-aerated subsurface-flow CWs have limitations in nitrogen removal, since the low availability of oxygen in the substrate compromises the nitrification process (Wu et al., 2015). The results obtained in the present study confirm these limitations, as can be seen in the $\mathrm{NH}_{4}{ }^{+}$and $\mathrm{TN}$ average removal efficiencies achieved in the CW1 system, which were $57.7 \%$ and $48.8 \%$, respectively. Similar results were also reported in the study developed by Hua et al. (2017), in which the authors obtained $\mathrm{NH}_{4}{ }^{+}$ and TN removal efficiencies in the ranges of, respectively, 20.7-66.9\% and 38.1-51.6\%.

Moreover, as stated above, the intermittently aerated system (CW2) showed high efficiency in the removal of $\mathrm{NH}_{4}{ }^{+}$and TN, with values of, respectively, 98.5 and $83.6 \%$. These results indicate, therefore, that the use of intermittent aeration allows the simultaneous occurrence of nitrification and denitrification, improving nitrogen removal performance of CWs. These results are similar to those obtained by Fan et al. (2016) and Wu et al. (2016). However, it is observed that the remaining fraction of nitrogen in the CW2 effluent is mainly composed of $\mathrm{NO}_{3} \cdot$. This fact indicates that complete denitrification has not occurred, probably due to the lack of organic matter (carbon). The occurrence of partial denitrification of the effluent due to the absence of organic carbon was also observed by Wu et al. (2016).

Vymazal and Kröpfelová (2008) concluded that, in most cases, the removal of TN in nonaerated horizontal subsurface-flow constructed wetlands is small (40-50\%), as these systems do not provide simultaneous aerobic and anaerobic conditions for the occurrence of nitrification and denitrification, respectively. On the other hand, the results of the present study show that the use of intermittent aeration allows nitrification and denitrification to occur simultaneously, increasing $\mathrm{CW}$ s performance in the removal of $\mathrm{TN}$ (CW2 was $35 \%$ more efficient than $\mathrm{CW} 1$ ).

\subsection{Total Phosphorus}

The results of the phosphorus analysis can be observed in Figure 4. Although they were considered satisfactory, since constructed wetlands are efficient in removing biochemical oxygen demand (BOD) and total suspended solids (TSS), phosphorus removal is still considered a challenge (De Rozari et al., 2015). Moreover, the results partly contradict the results of Ayaz et al. (2003) and Vymazal (2007); the former study stated that the phosphorus removal efficiency varies between 20 and $70 \%$, depending on the plant used and the feeding regime, while according to the latter, total phosphorus removal varies between 40 and $60 \%$ among all wetland systems.

The final phosphorus concentration in the CW1 was $1.58 \mathrm{mg} \mathrm{L}^{-1}$ and in the CW2 was 0.89 $\mathrm{mg} \mathrm{L}^{-1}$, representing average removal efficiencies of, respectively, $58.66 \%$ and $78.1 \%$. Although these results are much higher than those obtained by Mendonça et al. (2012), who obtained average removal efficiencies of $33.6 \%$ and $34.3 \%$ in CWs planted with cattails and with 2 days of HRT, they are similar to the results found by Ramos et al. (2017) who obtained, with 3.2 days of HRT, removal efficiencies of $51 \pm 24 \%, 69 \pm 22 \%$ and $45 \pm 19 \%$ in CWs without vegetation, planted with $P$. punctatum, and planted with and $C$. zizanioides, respectively. Fia $e t$ al. (2017) also reported high phosphorus removal efficiencies (73-78\%) in the treatment of swine wastewater in CWSs planted with cattails with HRT of 11.8-12 days. 


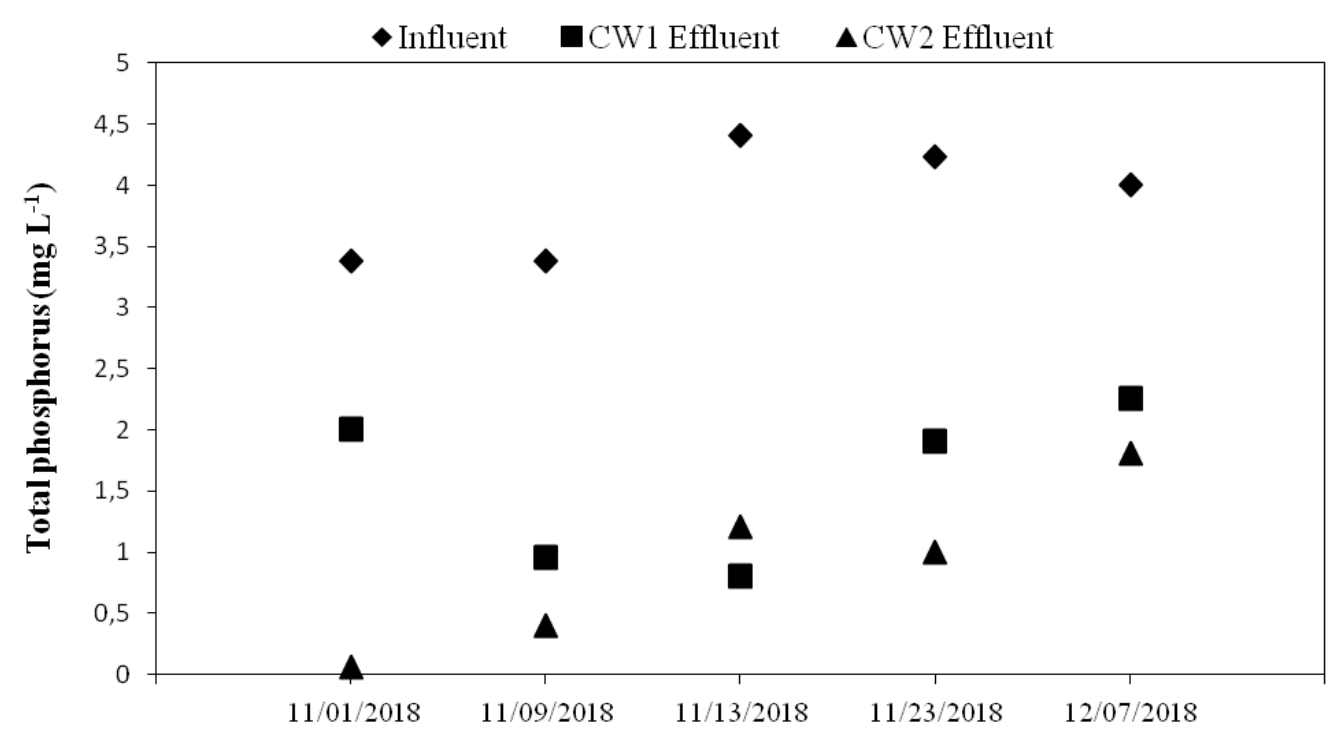

Figure 4. Total phosphorus input and output concentrations for both CWs.

It is noteworthy that the CW2 system was on average $~ 20 \%$ more efficient in removing TP than the CW1 system. This difference can be attributed to the use of intermittent aeration, as it promotes an increase in biological activity, including polyphosphate-accumulating organisms (PAOs). In addition, intermittent aeration also promotes the mixing of the effluent, a fact that intensifies the contact between phosphorus and the substrate and, consequently, improves the absorption of this nutrient by the support material. Shi et al. (2017) also reported significant improvements $(18-46 \%)$ in the removal of phosphorus in intermittently aerated vertical subsurface-flow constructed wetlands compared to non-aerated systems, both filled with gravel. The results obtained by these authors indicate that intermittent aeration increased TP accumulated by support material storage and also by microbial uptake

According to Vymazal (2007), phosphorus removal can be mainly associated with physical processes such as adsorption, precipitation, accumulation of organic matter in the substrate, microbial activity, and plant absorption. According to Greenway and Woolley (2001) plants play a significant role in removing phosphorus, being responsible for the absorption of up to $80 \%$ of this nutrient in CWs. However, other studies suggest that plants are responsible for only 4.81-22.33\% of phosphorus uptake (Wu et al., 2013; Dzakpasu et al., 2015) and therefore have no significant role in TP removal.

It is also important to note that the age of CWs has an impact on the phosphorus removal process. According to Fia et al. (2017) and Sousa et al. (2004), newly constructed wetlands have greater capacity to adsorb and precipitate phosphorus-based compounds and, over time, the system ends up saturated with these compounds, reducing their removal efficiency.

\section{CONCLUSIONS}

Based on the results obtained, it can be concluded that intermittent aeration increased the efficiency of organic matter removal (represented by COD) and nutrient removal mainly in the nitrification process. The best average values of COD (98.25\%), $\mathrm{NH}_{4}{ }^{+}(98.52 \%)$, TN $(83.6 \%)$, and TP $(78.1 \%)$ removal were obtained in the system using intermittent aeration, which demonstrates the importance of aeration in nitrogen removal by creating excellent aerobic and anaerobic conditions alternately; this also contributes to the removal of organic matter that is consumed in the denitrification process. It was observed that although intermittent aeration in a HRT greater than 3 days does not considerably improve the performance of COD removal as opposed to the results observed in the removal of the nitrogen species, it is an alternative that 
significantly increases the efficiency in the treatment of organic matter and nutrients in a HRT of less than 3 days. This suggests that it is an appropriate alternative for obtaining high performance in constructed wetland systems.

\section{ACKNOWLEDGMENTS}

The authors thank the São Paulo Research Foundation - (Fundação de Amparo à Pesquisa do Estado de São Paulo - FAPESP) for their financial support (Process nos. 2017/18075-8, 2018/04320-3 and 2019/20793-1).

\section{REFERENCES}

APHA; AWWA; WEF. Standard Methods for the examination of water and wastewater. 22nd ed. Washington, 2012. 1496 p.

AL-ISAWI, R. H. K.; SANAK, R.; SCHOLZ, M. Comparative study of domestic wastewater treatment by ponds and mature vertical-flow constructed wetlands. Ecological Engineering, v. 100, p. 8-18, 2017. https://doi.org/10.1016/j.ecoleng.2016.12.017

AL-ISAWI, R. H. K.; SANI, A.; ALMUKTAR, S.; SCHOLZ, M. Vertical-flow constructed wetlands treating domestic wastewater contaminated by hydrocarbons. Water Science and Technology, v. 71, n. 6, p. 938-946, 2015. https://doi.org/10.2166/wst.2015.054

AYAZ, S. Ç.; AKÇA, L.; TUNÇSIPER, B. Removal of organic, inorganic and microbial pollution from waters discharged to drinking water dams by constructed wetland systems. Project No:5022410. Istanbul: TUBITAK-Marmara Research Center, 2003.

BRASIL, M. S.; MATOS, A. T.; SOARES, A. A.; FERREIRA, P. A. Qualidade do efluente de sistemas alagados construídos, utilizados no tratamento de esgoto doméstico. Revista Brasileira de Engenharia Agrícola e Ambiental, v. 9, (Suplemento), p.133-137, 2005.

CIRIA, M. P.; SOLANO, M. L.; SORIANO, P. Role of macrophyte Typha latifolia in a constructed wetland for wastewater treatment and assessment of its potential as a biomass

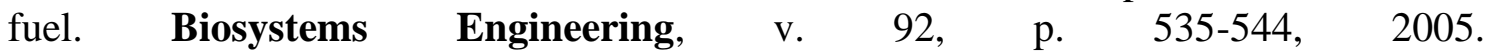
https://doi.org/10.1016/j.biosystemseng.2005.08.007

DZAKPASU, M.; SCHOLZ, M.; MCCARTHY, V.; JORDAN, S. Phosphorus retention and mass balance in an ICW system. Water Environ Journal, v. 29, p. 298-306, 2015. https://doi.org/10.1111/wej.12107

DE ROZARI, P.; GREENWAY, M.; EL HANANDEH, A. An investigation into the effectiveness of sand media amended with biochar to remove $\mathrm{BOD}_{5}$, suspended solids and coliforms using wetland mesocosms. Water Science and Technology, v. 71, p. 1536-1544, 2015.

FAN, J.; ZHANG, J.; GUO, W.; LIANG, S.; WU, H. Enhanced long-term organics and nitrogen removal and associated microbial community in intermittently aerated subsurface flow constructed wetlands. Bioresource Technology, v. 214, p. 871-875, 2016. https://doi.org/10.1016/j.biortech.2016.05.083

FIA, F. R. L. Modelos de remoção de matéria orgânica e nutrientes de águas residuárias da suinocultura em sistemas alagados construídos. 2009. $146 \mathrm{f}$. Tese (doutorado) Programa de pós-graduação em Engenharia Agrícola, Viçosa, 2009. 
FIA, F. R. L.; MATOS, A. T. D.; FIA, R., BORGES, A. C.; CECON, P. R. Efeito da vegetação em sistemas alagados construídos para tratar águas residuárias da suinocultura. Revista Brasileira de Eng. Sanitária e Ambiental, v. 22, n. 2, p. 303-311, 2017. https://doi.org/10.1590/S1413-41522016123972

GREENWAY, M.; WOOLLEY, A. Changes in plant biomass and nutrient removal over 3 years in a constructed wetland, Cairns, Australia. Water Science and Technology, v. 44, p. 303-310, 2001. https://doi.org/10.2166/wst.2001.0844

HUA, Y.; PENG, L.; ZHANG, S.; HEAL, K. V.; ZHAO, J.; ZHU, D. Effects of plants and temperature on nitrogen removal and microbiology in pilot-scale horizontal subsurface flow constructed wetlands treating domestic wastewater. Ecological Engineering, v. 108, p. 70-77, 2017. https://doi:10.1016/j.ecoleng.2017.08.007

LEE, C.; FLETCHER, T. D.; SUN, G. Nitrogen removal in constructed wetland systems.

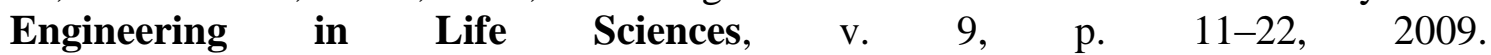
https://doi.org/10.1002/elsc.200800049

MATOS, A. T.; ABRAHÃO, S. S; BORGES, A. C.; MATOS, M. P. Influência da taxa de carga orgânica no desempenho de sistemas alagados construídos cultivados com forrageiras.

Revista Engenharia Sanitária e Ambiental, v. 15, n. 01, p. 83-92, 2010a. https://doi.org/10.1590/S1413-41522010000100010

MATOS, A. T.; FREITAS, W. S.; LO MONACO, P. A. V. Eficiência de sistemas alagados construídos na remoção de poluentes de águas residuárias da suinocultura. Revista Ambiente \& Água, v. 5, n. 2, p. 119-132, 2010b. https://doi.org/10.4136/ambi-agua.142

MATOS, A. T.; LO MONACO, P. A. Tratamento e aproveitamento agrícola de resíduos sólidos e líquidos da lavagem e despolpa de frutos do cafeeiro. Viçosa: UFV, 2003. 68p. Boletim técnico.

MENDONÇA, H. V.; RIBEIRO, C. B. M.; BORGES, A. C.; BASTOS, R. R. Remoção de nitrogênio e fósforo de águas residuárias de laticínios por sistemas alagados construídos operando em bateladas. Revista Ambiente \& Água, v. 7, n. 2, p. 75-87, 2012. https://doi.org/10.4136/ambi-agua.805

RAMOS, N. D. F. S; BORGES, A. C.; GONÇALVES, G. C.; MATOS, A.T. D. Tratamento de águas residuárias de suinocultura em sistemas alagados construídos, com Chrysopogon zizanioides e Polygonum punctatum cultivadas em leito de argila expandida. Engenharia Sanitária e Ambiental, v. 22, n. 01, p. 123-132, 2017. https://doi.org/10.1590/S14134152201687067

SHI, X.; FAN, J.; ZHANG, J.; SHEN, Y. Enhanced phosphorus removal in intermittently aerated constructed wetlands filled with various construction wastes. Environmental Science and Pollution Research, v. 24, p. 22524-22534, 2017. https://doi.org/10.1007/s11356-017-9870-z

SOUSA, J. T.; VAN HAANDEL, A. C.; LIMA, E. P. C.; HENRIQUE, I. N. Utilização de wetland construído no pós-tratamento de esgotos domésticos pré-tratados em reator UASB. Revista de Engenharia Sanitária e Ambiental, v. 9, n. 4, p. 285-290, 2004. http://dx.doi.org/10.1590/S1413-41522004000400004 
SULIMAN, F.; FRENCH, H.; HAUGEN, L.; KLØVE B.; JENSSEN, P. The effect of scale on the flow and transport parameters in horizontal subsurface flow constructed wetlands. In: INTERNATIONAL CONFERENCE ON WETLAND SYSTEMS FOR WATER POLLUTION CONTROL, 9., 26th of Sept. - 1st of October 2004, Avignon, France. Proceedings[...] Nanterre: IWA/Astee, 2004. 1 CD-ROM.

VYMAZAL, J. Removal of nutrients in various types of constructed wetlands. Science of the $\begin{array}{lllllll}\text { Total Environment, } & \text { v. } 380, \quad \text { n. } 1-3, & \text { p. }\end{array}$ https://doi.org/10.1016/j.scitotenv.2006.09.014

VYMAZAL, J.; KRÖPFELOVÁ, L. Wastewater Treatment in Constructed Wetlands with Horizontal Subsurface Flow. [S.1.]: Springer, 2008. V. 14.566 p. https://doi.org/10.1007/978-1-4020-8580-2

WANG, W.; DING, Y.; WANG, Y.; SONG, X.; AMBROSE, R. F.; ULLMAN, J. L.; GONG, J. Treatment of rich ammonia nitrogen wastewater with polyvinyl alcohol immobilized nitrifier biofortified constructed wetlands. Ecological Engineering, v. 94, p. 7-11, 2016. https://doi.org/10.1016/j.ecoleng.2016.05.078

WENDLING, A. C. Remoção simultânea de matéria orgânica e nitrogênio total em reator de leito estruturado com aeração intermitente tratando efluente composto por esgoto bruto e efluente de ralf. 2017. Dissertação (Mestrado) - Universidade Estadual de Ponta Grossa, Ponta Grossa, 2017.

WU, H.; ZHANG, J.; LI, C.; FAN, J.; ZOU, Y. Mass balance study on phosphorus removal in constructed wetland microcosms treating polluted river water. CLEAN - Soil Air Water, v. 41, p. 844-850, 2013. https://doi.org/10.1002/clen.201200408

WU, H.; FAN, J.; ZHANG, J.; NGO, H. H.; GUO, W.; HU, Z.; LIANG, S. Decentralized domestic wastewater treatment using intermittently aerated vertical flow constructed wetlands: impact of influent strengths. Bioresource Technology, v. 176, p. 163-168, 2015. https://doi.org/10.1016/j.biortech.2014.11.041

WU, H.; FAN, J.; ZHANG, J.; NGO, H. H.; GUO, W.; LIANG, S.; LV, J.; LU, S.; WU, W.; WU, S. Intensified organics and nitrogen removal in the intermittent-aerated constructed wetland using a novel sludge-ceramsite as substrate. Bioresource Technology, v. 210, p. 101-107, 2016. https://doi:10.1016/j.biortech.2016.01.051 